\title{
A NEST PREDATOR'S VIEW OF A MANAGED FOREST: GRAY JAY (PERISOREUS CANADENSIS) MOVEMENT PATTERNS IN RESPONSE TO FOREST EDGES
}

\author{
Jacques Ibarzabal ${ }^{1}$ and André Desrochers \\ Centre de Recherche en Biologie Forestière, Faculté de Foresterie et de Géomatique, Université Laval, Ste-Foy, \\ Québec G1K 7P4, Canada
}

\begin{abstract}
Авstract. - High nest-predation risk is often associated with forest edges. Most nest predators in boreal coniferous forests of North America are forest specialists living in mature stands. Nest predators have been studied mainly through use of artificial nests; knowledge of their behavior remains limited. We used radiotelemetry to examine movement patterns, relative to forest edge, of a forest nest predator, the Gray Jay (Perisoreus canadensis), in boreal coniferous forest. Each of 11 family groups of Gray Jays monitored in early summer exhibited a marked association with forest edges. Jays were found within $30 \mathrm{~m}$ of the forest edges more often than expected from random use of mature forest. Furthermore, jays traveled more slowly near forest edges than in the forest interior. Because forest edges apparently represent prime foraging habitat for Gray Jays, narrow forest strips left by logging could act as ecological traps for mature-stand songbirds before stands regenerate in adjacent clearcuts. Received 19 March 2003, accepted 5 October 2003.
\end{abstract}

Résumé.-Un risque élevé de prédation est souvent associé aux lisières des forêts. La plupart des prédateurs de nids des forêts conifériennes boréales de l'Amérique du Nord sont essentiellement des espèces du milieu forestier mature. Les prédateurs de nids ont surtout été étudiés à l'aide de nids artificiels et la connaissance de leur comportement reste limitée. Nous avons utilisé la télémétrie conventionnelle pour examiner les patrons de mouvement relatifs aux lisières des forêts par un prédateur de nid forestier, Perisoreus canadensis, dans une forêt coniférienne boréale. Chacun des 11 groupes familiaux de Perisoreus canadensis suivis au début de l'été montraient une association marquée avec les lisières. Les mésangeais ont été trouvés plus souvent à moins de $30 \mathrm{~m}$ d'une lisière forestière que l'aurait suggérée une répartition aléatoire de leurs activités dans la forêt mature. De plus, les mésangeais se déplaçaient plus lentement près des lisières qu'à l'intérieur de la forêt. Étant donné que les lisières représentent apparemment un habitat privilégié pour la quête de nourriture chez Perisoreus canadensis, les bandes étroites de forêts laissées après les coupes forestières pourraient constituer des pièges écologiques pour les passereaux de la forêt mature, avant que les peuplements se régénèrent dans les coupes adjacentes.

Nest pRedation is one of the most important factors affecting nesting success (Ricklefs 1969). The risk of nest predation varies according to the predatory community involved, nest location (e.g. on the ground or in trees), and bird species (Møller 1989, Nour et al. 1993, Tewksbury et al. 1998, Yahner and Piergallini 1998). Many studies have shown that forest edges in agricultural landscapes (Andrén 1995, Henske et al. 1999) and occasionally in managed forests (Angelstam 1986, Andrén 1995, Bayne

\footnotetext{
${ }^{1}$ Present address: Consortium de Recherche sur la Forêt Boréale Commerciale, Département des Sciences Fondamentales, Université du Québec à Chicoutimi, 555 boulevard de 1'Université, Chicoutimi, Québec G7H 2B1, Canada. E-mail: jacques_ibarzabal@uqac.ca
}

and Hobson 1997) are associated with high nest-predation risk.

The high risk of nest predation near forest edges is usually attributed to opportunistic species invading forests from other nearby habitats (DeGraaf 1995). However, forest-dwelling nest predators can also have a significant effect on nests near forest edges (Andrén 1995). In fact, nest predators of managed boreal forests seem mainly to be forest specialists rather than species occurring in agricultural fields or urban fringes (Andrén 1995, Bayne and Hobson 1997, Darveau et al. 1997). Although risk of nest predation near forest edges is well documented, knowledge of the underlying processes - predator behavior in particular-remains limited for both temperate and boreal regions. 
Logging in coniferous boreal forests typically creates landscapes that are dominated by clearcuts and regeneration. In Quebec, Canada, $\sim 300,000$ ha of boreal forest are logged annually (Parent 1999). Forest remnants are generally linear and appear mostly as riverine bands $(20 \mathrm{~m})$ and forest strips of 60 or $100 \mathrm{~m}$ between clearcuts (Ministère des Ressources Naturelles du Québec 1996). The resulting landscape structure may affect songbirds, nest predators, and their relationships, particularly if nest predators prefer to forage near edges.

We examined movement patterns of the Gray Jay (Perisoreus canadensis), a species commonly found in boreal coniferous forests (Strickland and Ouellet 1993). Like many other members of the Corvidae (Andrén 1995), Gray Jays are nest predators (Bayne and Hobson 1997, Sieving and Willson 1998, Boulet and Darveau 2000, Boulet et al. 2000) and use eggs and nestlings as main food items (Strickland and Ouellet 1993). Gray Jays have been observed preying on eggs or nestlings of many bird species (Spruce Grouse [Dendragapus canadensis], Ruby-crowned Kinglet [Regulus calendula], Swainson's Thrush [Catharus ustulatus], Hermit Thrush [C. guttatus], American Robin [Turdus migratorius], Magnolia Warbler [Dendroica magnolia], Lincoln's Sparrow [Melospiza lincolnii], Fox Sparrow [Passerella iliaca], White-crowned Sparrow [Zonotrichia leucophrys], White-throated Sparrow [Z. albicollis]; Bent 1946, Ouellet 1970). Given that higher nest predation rates by Gray Jay were recorded near forest edges (Bayne and Hobson 1997, Sieving and Willson 1998), we tested the prediction that foraging Gray Jays are associated with forest edges during the nesting season.

\section{Study Area and Methods}

Study area.-Fieldwork was conducted at Forêt Montmorency, Quebec $\left(47^{\circ} 13^{\prime}-47^{\circ} 29^{\prime} \mathrm{N} ; 71^{\circ} 05^{\prime}-71^{\circ} 15^{\prime} \mathrm{W}\right)$ and its vicinity, a total area of $430 \mathrm{~km}^{2}$. Study sites were all located in balsam fir (Abies balsamea) stands, occasionally with scattered white birch (Betula papyrifera) or black spruce (Picea mariana). Mature stands were 15 to $18 \mathrm{~m}$ high. On the basis of habitat descriptions by Strickland and Ouellet (1993), all mature stands in the study area appeared suitable to Gray Jays. Shrub, herbaceous, and moss strata in those stands were composed mainly of A. balsamea, Acer spicatum, Oxalis montana, Cornus canadensis, Gaultheria hispidula, Clintonia borealis, Pleurozium schreberi, and Hylocomium splendens. Spruce budworm (Choristoneura fumiferana) outbreaks were the most common natural disturbance. Early seral stages were dominated by stands of white birch and balsam fir. Clearcuts were colonized by Rubus idaeus, A. balsamea, B. papyrifera, Picea glauca, Prunus pensylvanica, and locally by graminoids. The study area comprised mature coniferous stands $(49 \%)$, mixed regeneration $(35 \%)$, clearcuts and severe windthrow $(15 \%)$, and open water $(1 \%)$ (Drolet et al. 1999). A road network of $1,100 \mathrm{~km}$ covered all parts of the study area, including large uncut mature forests. Edges with clearcuts showed high contrast and no associated vegetation (in species or structure) developed in the mature forest edge while clearcuts regenerated. A complete description of the study area can be found in Darveau et al. (1997).

Among the 50 woodland songbird species found in the study area (Drolet et al. 1999), 28 are of high conservation concern according to Dunn et al. (1999). The most frequent species were Yellow-rumped Warbler (D. coronata), Golden-crowned Kinglet ( $R$. satrapa), Ruby-crowned Kinglet, Blackpoll Warbler (D. striata), Bay-breasted Warbler (D. castanea), Black-throated Green Warbler (D. virens), Magnolia Warbler, Darkeyed Junco (Junco hyemalis), Swainson's Thrush, and White-throated Sparrow (for complete list see Drolet et al. 1999). The main nest predators in the study area were red squirrel (Tamiasciurus hudsonicus), Gray Jay, and mice and voles (Peromyscus and Clethrionomys spp.; Darveau et al. 1997, Boulet and Darveau 2000, Ibarzabal and Desrochers 2001). During the study, Gray Jays were present at low population-density over the study area (one family group per $15 \mathrm{~km}^{2} ; \mathrm{J}$. Ibarzabal pers. obs.). Other potential nest predators were American Marten (Martes americana), ermine (Mustela erminea), short-tailed shrew (Blarina brevicauda), northern flying squirrel (Glaucomys sabrinus), eastern chipmunk (Tamias stratus), Common Raven (Corvus corax), and Rusty Blackbird (Euphagus carolinus) (Darveau et al. 1997, Boulet and Darveau 2000).

Locating Gray Jays. - We monitored movements of four adult Gray Jays from 9 June through 2 July 1996 and seven adult Gray Jays from 10 June through 15 July 1997, during the nesting period of songbirds (Gauthier and Aubry 1995). Each monitored jay was from a different family group composed of two adults and one to three juveniles. Approximately $30 \%$ of the resident Gray Jay population in the study area was monitored (J. Ibarzabal pers. obs). Monitored birds were selected in all parts of the study area, with forest cover ranging from 20 to $94 \%$ (Table 1). Jays were captured and fitted with a tail-mounted radiotransmitter (Holohil [Carp, Ontario], Model BD-2G; Animal-welfare protocols 95-006, 96-022, and 97-011). All radiotracked groups of jays were first located by telemetry and then followed visually from a range of $30-100 \mathrm{~m}$. In the visual cases (450 location records), positions were obtained with a Global Positioning System (GPS) receiver held directly under perches 
after they were left vacant by birds. GPS locations were differentially corrected with data collected at a base station located $70 \mathrm{~km}$ from the study area. Bird locations were obtained with GPS averages from $>100$ fixes and were accurate to $\pm 2 \mathrm{~m}$, based on satellite configurations used (Precision Dilution of Position < 6.0; Hurn 1993).

When visual contact with birds was not possible ( $n=499$; mainly when they foraged on soil or $>50 \mathrm{~m}$ into forest), positions were triangulated from radio signals. To assess the precision of locations obtained by triangulation, compass reading errors were obtained by placing transmitters on fixed locations unknown to the observer and by comparing estimated and real locations $(n=178)$. A reading error of $<10^{\circ}$ was obtained in $67 \%$ of all cases tested (range of all values: -22 to $+27^{\circ}$ ). To minimize location errors from triangulation, two radiolinked observers simultaneously recorded the azimuth of signals from angles differing by $\sim 90^{\circ}$, within $200 \mathrm{~m}$ of birds in $84 \%$ of cases. Observers positioned themselves with a GPS receiver. The mean area of error for polygons was calculated according to White and Garrot (1990) and was $0.19 \pm 0.17$ ha. Jays with transmitters were considered "sample units." However, jays were always in family group and were seldom farther than $50 \mathrm{~m}$ apart (J. Ibarzabal pers. obs.). Before accounting for spatial autocorrelation (see below), subsequent locations were recorded every $10 \mathrm{~min}$ (over $3-8$ days; $5 \pm 1.5$; mean \pm $1 \mathrm{SD})$ from 0500 to 1200 hours $(n=803)$ and 1300 to 1630 hours EST $(n=146)$.

Distance to forest edges.-Black-and-white aerial photos $(1: 10,000$ or $1: 15,000)$ of the area used by each group of jays were digitized with a resolution of 600 DPI and georeferenced using 5-10 known locations. Pixel size varied between 1.4 and $2.0 \mathrm{~m}$ and corresponded roughly to the measurement error of the locations established with the GPS. Edges between mature forests (height $>8 \mathrm{~m}$ ) and clearcuts, bodies of water, and roads were manually digitized. Convex polygons were used to enclose all locations of each group of jays. Inside each polygon, a 10-m dot grid was overlaid on all forest surfaces, thereby reflecting the set of locations available for each group of jays (for rationale and methods, see Desrochers and Fortin 2000). Distance to the closest edge was calculated for each bird and grid location. One-sample $t$-tests were used to compare each bird's mean distance to forest edge with the mean distance to edge of all grid locations.

Because sample units for each group of jays were single locations, and to avoid pseudoreplication, autocorrelation was assessed with distance-to-time plots (Redpath 1995, Otis and White 1999). Gray Jay locations were recorded either singly $(n=41)$ or in 122 sets of 2-35 locations totaling 908 locations separated by 10 min $(8 \pm 6$ locations per set; mean \pm 1 SD). Spatial autocorrelation of locations was assessed by plotting the relationship between net distance traveled during the 10-min segment of each set of observations and cumulative observation time for all birds combined (Fig. 1; Redpath 1995). The curve reached an asymptote at $90 \mathrm{~min}$. Consequently, for each individual, comparison of the means of the observed and available locations was completed using observed locations that were separated by at least 90 min (i.e. considered independent).

Movement rates. - Rates of movement were evaluated using the distance traveled within a 10-min interval. For each 10-min interval, a movement midpoint was calculated as mean coordinates between initial and final locations. A 1-ha' grid of dots, spaced by $10 \mathrm{~m}$ and centered on each midpoint, was used to describe edge patterns where movements occurred $(n=786)$. Distance to the edge was calculated for each dot on the grid (excluding dots outside forest patches), and mean distance to the edge was thus obtained for each grid. Number of forested dots on the grid was used as a measure of the proportion of forest in each $1 \mathrm{ha}^{2}$. A multiple regression of distance moved by Gray Jays as a function of distance to edge and the amount of forest within 1 ha of movement midpoint was run for each family group. Parameter estimates for each family group were then saved and their values compared to zero using a one-sample $t$-test.

\section{Results}

A total of 949 locations were recorded for a mean of $86 \pm 2.41$ locations per group (mean $\pm 1 \mathrm{SE}$; range =70-105). All groups were observed on at least three days. A map showing the locations of one group of jays is presented in Figure 2. Five percent of locations were in recent ( $<7$ years) clearcuts; $1 \%$ of locations were $>50 \mathrm{~m}$ outside forests.

Edge proximity.-Groups of jays exhibited a marked association with forest edges, relative to all locations in forest within the convex polygon (Table 1). Association with edge was strong regardless of the amount of forest within their home range, which varied from 20\% to

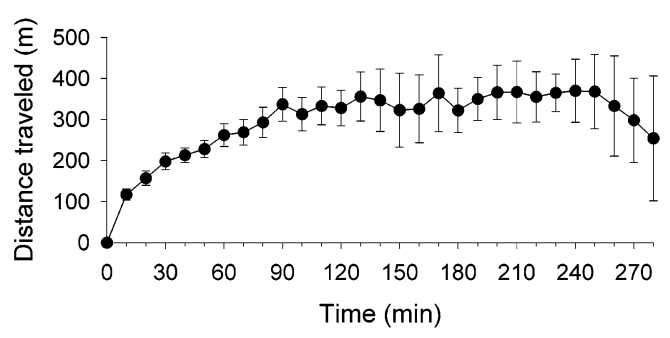

FIG. 1. Relationship between time and distance traveled from initial locations for Gray Jay. Points shown as means $\pm 1 \mathrm{SE}$. 


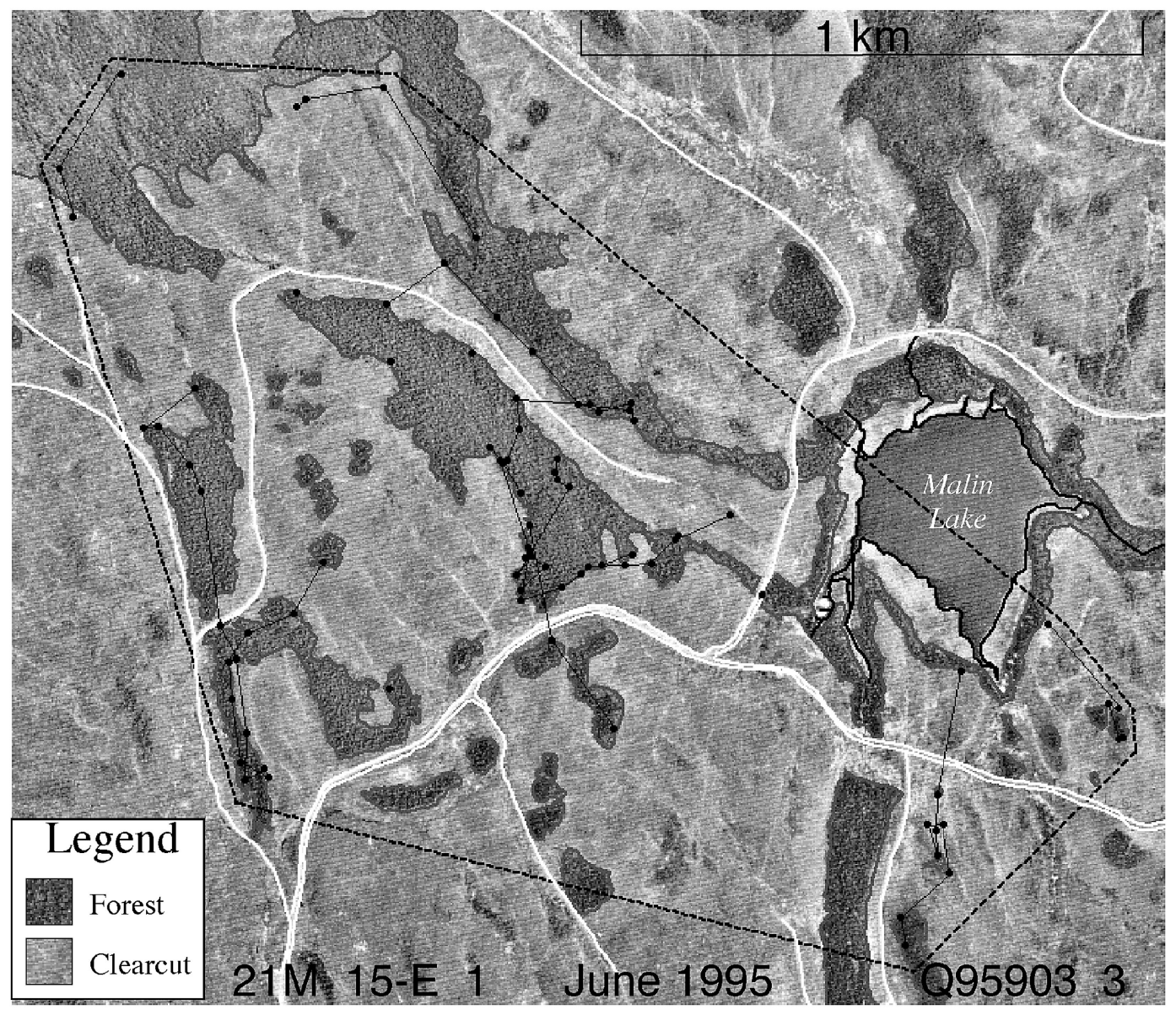

FIG. 2. Map showing the position of Gray Jays (group picked at random; 97-599) located in the vicinity of Forêt Montmorency, Quebec. Solid black lines denote movement of jays, dashed black lines denote minimum convex polygon, white lines denote road, and dots identify jay location.

TABLE 1. Comparison of edge proximity between observed and available positions for Gray Jay family groups in managed boreal forest in Quebec.

\begin{tabular}{|c|c|c|c|c|c|c|}
\hline \multirow[b]{2}{*}{ Group } & \multirow{2}{*}{$\begin{array}{l}\text { Percent forest } \\
\text { in home range }\end{array}$} & \multicolumn{3}{|c|}{ Distance of jay to edge (m) } & \multirow{2}{*}{$\begin{array}{l}\text { Mean distance to edge } \\
\text { in convex polygon }(\mathrm{m})\end{array}$} & \multirow[b]{2}{*}{$P$} \\
\hline & & $n$ & $\bar{x}$ & SE & & \\
\hline 96-019 & 78.3 & 13 & 69.8 & 25.7 & 145.2 & $=0.012$ \\
\hline 96-059 & 8 & 12 & 20.9 & 4.6 & 44.3 & $<0.001$ \\
\hline $96-080$ & 66.7 & 14 & 18.3 & 3.6 & 45.2 & $<0.001$ \\
\hline $96-119$ & 80.2 & 10 & 21.3 & 5.6 & 53.5 & $<0.001$ \\
\hline $97-080$ & 53.7 & 16 & 11.4 & 2.0 & 54.8 & $<0.001$ \\
\hline $97-201$ & 93.6 & 15 & 59.4 & 17.3 & 126.9 & $=0.002$ \\
\hline $97-599$ & 20.4 & 18 & 8.7 & 3.6 & 23.1 & $<0.001$ \\
\hline $97-699$ & 54.9 & 14 & 10.7 & 3.9 & 40.9 & $<0.001$ \\
\hline $97-778$ & 74.7 & 21 & 20.6 & 5.1 & 61.1 & $<0.001$ \\
\hline $97-798$ & 55.8 & 16 & 7.6 & 1.7 & 29.7 & $<0.001$ \\
\hline 97-G35 & 36.5 & 12 & 10.2 & 1.9 & 24.0 & $<0.001$ \\
\hline
\end{tabular}


94\% (Table 1). The association of jays to edges tended to be stronger in home ranges with larger amounts of forest (Spearman's $r_{\mathrm{s}}=0.55$, $P=0.08)$. Groups of jays were found within $30 \mathrm{~m}$ of forest edges more often than expected given the landscape structure within their convex polygon (Fig. 3). Seventy-six percent of jay locations were $<30 \mathrm{~m}$ from a forest edge, even though only $46 \%$ of mature forest was $<30 \mathrm{~m}$ from edges (all home ranges combined).

Movement rates. - Gray Jays moved $93 \pm 3.3 \mathrm{~m}$ (mean $\pm 1 \mathrm{SE}$ ) within 10-min intervals. Their movement rate was influenced by the proximity and amount of forest edges, as measured by the mean distance to edge of woodland within 1 ha of movement midpoint (Fig. 4). Groups of jays moved more slowly near forest edges than far from them, after the amount of forest within 1 ha was accounted for (least-squares, multiple regression, mean coefficient for edge distance $=2.14, \mathrm{SE}=0.54, n=11$ jays, $t=4.0$, $P=0.003$ ). The amount of forest in 1-ha squares centered on movement midpoints was not associated with movement rate, when distance to forest edge was accounted for (multiple regression, mean coefficient for percentage of forest cover $=-0.6, \mathrm{SE}=1.1, n=11, t=-1.7, P=0.10)$. However, when accounting for linear effects of edge and forest cover, there was a nonlinear effect of forest cover on jay mobility (regression coefficient for quadratic effect $=0.034, \mathrm{SE}=$ $0.018, n=11, t=2.90, P=0.02)$.

\section{Discussion}

Edge proximity.-During the egg and nestling period of most songbirds, Gray Jays were closely associated with forest edges. That association was not simply the result of the large amount of edge habitat in home ranges; the association of jays with edges relative to their availability was stronger in more forested home ranges. The association between jays and edges is consistent with other studies of jays (Bayne and Hobson 1997, Sieving and Willson 1998) and with studies of other corvid species (Andrén 1992, Hannon and Cotterill 1998) including the Siberian Jay (Perisoreus infaustus; Sklepkovych 1997), which is considered a palearctic ecological equivalent to the Gray Jay (Imbeau et al. 2001).

Animal responses to edges are not a new issue (Kremsater and Bunnell 1999), but only a few studies have focused on movements of

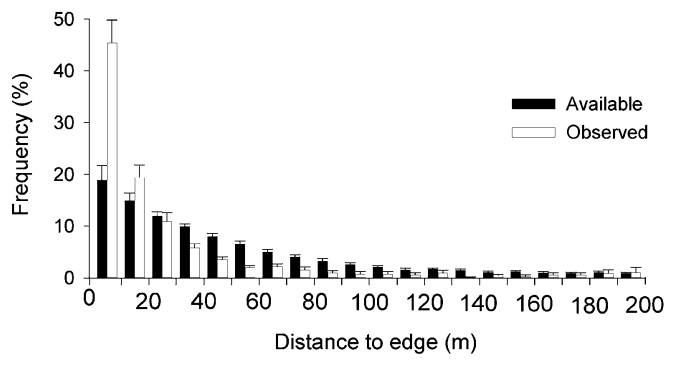

FIG. 3. Mean observed and available frequencies of Gray Jay occurrence at various distances from forest edges. Vertical bars represent $1 \mathrm{SE}$.
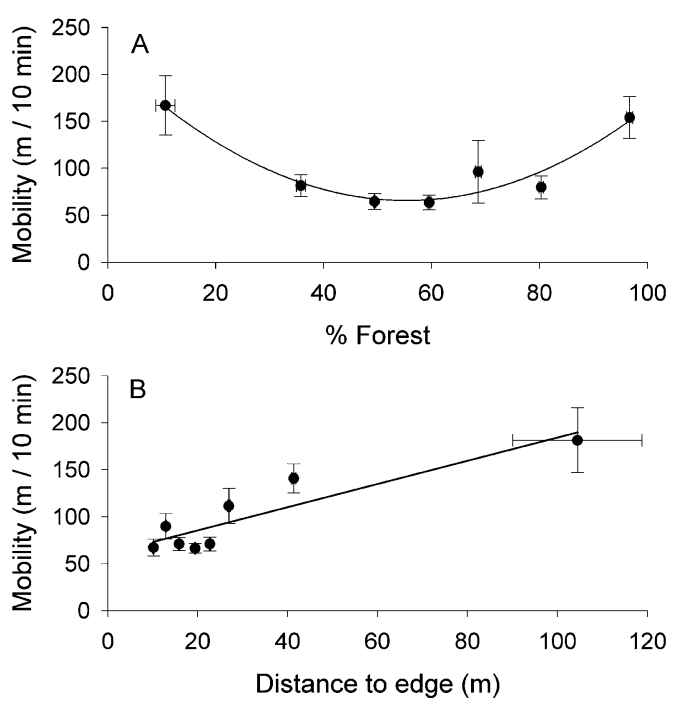

FIG. 4. Distance traveled by Gray Jay in $10 \mathrm{~min}$ in relation to (A) percentage of forest cover within 1 ha; and (B) mean distance to edges from all forest habitat within 1 ha. Points show mean distances traveled by jays $(n=11)$. Vertical and horizontal bars represent $\pm 1 \mathrm{SE}$.

birds near edges (e.g. Sisk and Margules 1993, Desrochers and Fortin 2000). To our knowledge, the present study provides the first direct evidence of edge-specific foraging by a nest predator, with $76 \%$ more time spent near edges $(<30 \mathrm{~m})$ than expected from availability. Sample sizes were small, but we argue that this is not a cause for concern given the large size of the effects and the fact that Gray Jay groups monitored ( $30 \%$ of the region's family groups) were selected over the entire study area.

The spatial extent of attraction of groups of jays to the edges was small ( $<30 \mathrm{~m}$; Fig. 3$)$. Although $30 \mathrm{~m}$ is a short distance relative to 
jay movement, nearly half of all woodland in the study area was $<30 \mathrm{~m}$ from an edge. On the basis of our study, linear stands left by logging in managed boreal forests of Quebec (generally $<100 \mathrm{~m}$ wide) can therefore be considered prime foraging habitat for Gray Jays, at least for the period during which adjacent clearcuts regenerate (approximately $20-30$ years).

Forest edges influenced the rate at which groups of jays moved through their home range (Fig. 4B). Our field observations suggest that low movement rates corresponded mainly to searching behavior, during which groups of jays typically examined trees and open soil along forest edges and then flew several hundred meters to another edge (Fig. 2). The curvilinear relationship between jay mobility and forest cover is consistent with the tendency of jays to slow down near forest edges (Fig. 4A), because edges are more prevalent in landscapes with intermediate forest cover than with extremely high or low forest cover (Drolet et al. 1999, Boulet et al. 2000). The precision of locations, especially triangulated ones, was admittedly small relative to movement rates, and may have partly obscured the relationships measured above. Thus, our assessment of movement-rate changes relative to edges is a conservative one.

Why were Gray Jays associated with forest edges? - At least three hypotheses can be formulated to explain the high occurrence of Gray Jays near edges between clearcut and forest. First, they could be attracted to recent clearcuts (Angelstam 1986, Vickery et al. 1992), but given that jays were rarely found outside forest stands $(<5 \%$ of the time), this hypothesis can be ruled out. Second, independently of food density near forest edges, movements of Gray Jays could be channeled along edges (Bider 1968). Consequently, relatively more time would be spent along them. The third hypothesis involves food availability. Gray Jays commonly feed on a variety of foods, including fruits, insects, birds (egg, nestling, adult), mushrooms, small mammals, and dead animals (Strickland and Ouellet 1993). During observations, groups of jays were almost constantly searching in trees. Although Gray Jays are known to scatter-hoard food (Strickland and Ouellet 1993), retrieval of food from caches is unlikely in summer, when fresh food is presumably very abundant. Instead, groups of jays could target forest edges for food because those habitat interfaces may exhibit more bird nests (Gates and Gysel 1978, Chasko and Gates 1982) or more arthropods (Jokimäki et al. 1998) than the forest interior, despite the lack of edge-specific vegetation. Sklepkovych (1997) found that Siberian Jays experienced higher nesting success near forest edges than away from them, and argued that enhanced foraging conditions at forest edges may be the cause. Additionally, Gray Jays are known to be visual hunters (Strickland and Ouellet 1993); even if forest edges do not provide more food than forest interior, those prey may be more detectable near well-defined edges. We argue that the slower pace of groups near edges is consistent with those food hypotheses. However, the actual mechanism resulting in the observed edge association remains undemonstrated.

Nest predators associated with forest edges may come from inside the forest, particularly in boreal coniferous-forested landscapes (Andrén 1995, Bayne and Hobson 1997, Darveau et al. 1997). As we have shown, Gray Jays are strongly associated with sharp edges, such as those created by logging. Given the fact that small forest songbirds rarely accommodate sizeable tracts of open area within their territory (Rail et al. 1997), it seems reasonable to expect that forest songbirds will decrease in numbers roughly proportional to or exceeding the proportion of forest cover loss (Andrén 1994, Fahrig 1997, Bender et al. 1998). Furthermore, because Gray Jays exhibit a marked association with forest edges regardless of the amount of forest in their home range, increased edge habitat associated with clearcuts may benefit jays more than most forest songbirds. Thus, as proposed by Henske et al. (1999) for agricultural edges with mammalian nest predators, it is possible that forest patches or strips left behind by the logging industry, in accordance with provincial regulations, will represent an ecological trap for songbirds, particularly in regions with larger populations of Gray Jays than were present in our study area.

\section{Acknowledgments}

We are grateful to J. Brazeau for his work as a field assistant, and to the Forêt Montmorency employees for their logistical assistance. We also thank A. Arseneault for his help with map georeferencing, and M. Bélisle, J. Bourque, M. Darveau, B. Drolet, J. Huot, L. Imbeau, M. Mazerolle, R. Saint-Laurent, and M.-A. Villard for their helpful comments on 
drafts of the manuscript. This research was funded by the "Fonds pour la formation des chercheurs et l'aide à la recherche" (FCAR, Québec), through a scholarship to J. Ibarzabal and a research grant to A. Desrochers, and by Fondation de 1'Université Laval and Centre de Recherche en Biologie Forestière grants to J. Ibarzabal.

\section{Literature Cited}

Andrén, H. 1992. Corvid density and nest predation in relation to forest fragmentation: A landscape perspective. Ecology 73:794-804.

Andrén, H. 1994. Effects of habitat fragmentation on birds and mammals in landscapes with different proportions of suitable habitat: A review. Oikos 71:355-366.

Andrén, H. 1995. Effect of landscape composition on predation rates at habitat edges. Pages 225-255 in Mosaic Landscape and Ecological Processes (L. Hansson, L. Fahrig, and G. Merriam, Eds.). Chapman and Hall, London.

Angelstam, P. 1986. Predation on ground-nesting birds' nests in relation to predator densities and habitat edge. Oikos 47:365-373.

Bayne, E. M., and K. A. Hobson. 1997. Comparing the effects of landscape fragmentation by forestry and agriculture on predation of artificial nests. Conservation Biology 11:1418-1429.

Bender, D. J., T. A. Contreras, and L. Fahrig. 1998. Habitat loss and population decline: A meta-analysis of the patch size effect. Ecology 79:517-533.

BENT, A. C. 1946. Life histories of North American jays, crows and titmice, Part 1. United States National Museum Bulletin, no. 191.

Bider, J. R. 1968. Animal activity in uncontrolled terrestrial communities as determined by a sand transect technique. Ecological Monographs 38:269-308.

Boulet, M., and M. Darveau. 2000. Depredation of artificial bird nests along roads, rivers and lakes in a boreal balsam fir forest. Canadian Field-Naturalist 114:83-88.

Boulet, M., M. Darveau, and L. Bélanger. 2000. A landscape perspective of bird nest predation in a managed boreal black spruce forest. Écoscience 7:281-289.

Chasko, G. G., And J. E. Gates. 1982. Avian habitat suitability along a transmission-line corridor in an oak-hickory forest region. Wildlife Monographs, no. 82.

Darveau, M., L. Bélanger, J. Huot, É. Mélançon, and S. DeBellefeuille. 1997. Forestry practices and the risk of bird nest predation in a boreal coniferous forest. Ecological Applications 7: 572-580.
DeGraAf, R. M. 1995. Nest predation rates in managed and reserved extensive northern hardwood forests. Forest Ecology and Management 79:227-234.

Desrochers, A., And M.-J. Fortin. 2000. Understanding avian responses to forest boundaries: A case study with chickadee winter flocks. Oikos 91:376-384.

Drolet, B., A. Desrochers, and M.-J. Fortin. 1999. Are songbirds affected by landscape structure in exploited boreal forest? Condor 101: 699-704.

Dunn, E. H., D. J. T. Hussell, and D. A. Welsh. 1999. Priority-setting tool applied to Canada's landbirds based on concern and responsibility for species. Conservation Biology 13: 1404-1415.

FAHRIG, L. 1997. Relative effects of habitat loss and fragmentation on population extinction. Journal of Wildlife Management 61:603-610.

Gates, J. E., AND L. W. Gysel. 1978. Avian nest dispersion and fledgling success in field-forest ecotones. Ecology 59:871-883.

Gauthier, J., And Y. Aubry. 1995. Les Oiseaux Nicheurs du Québec: Atlas des Oiseaux Nicheurs du Québec Méridional. Association québécoise des groupes d'ornithologues, Société québécoise de protection des oiseaux, Service canadien de la faune, Montréal, Québec.

Hannon, S. J., and S. E. Cotterill. 1998. Nest predation in aspen woodlots in an agricultural area in Alberta: The enemy from within. Auk 115:16-25.

Henske, E. J., S. K. Robinson, and J. D. Brawn. 1999. Predator activity and predation on songbird nests on forest-field edges in east-central Illinois. Landscape Ecology 14:345-354.

Hurn, J. 1993. Differential GPS Explained. Trimble Navigation, Sunnyvale, California.

IbArzabal, J., AND A. Desrochers. 2001. Lack of relationship between forest edge proximity and nest predator activity in an eastern Canadian boreal forest. Canadian Journal of Forest Research 31:117-122.

Imbeau, L., M. Mönkkönen, And A. Desrochers. 2001. Long-term effects of forestry on birds of the eastern Canadian boreal forests: A comparison with Fennoscandia. Conservation Biology 15:1151-1162.

Joкiмӓкі, J., E. Huhta, J. Iт̈̈мies, And P. Rahкo. 1998. Distribution of arthropods in relation to forest patch size, edge, and stand characteristics. Canadian Journal of Forest Research 28: 1068-1072.

Kremsater, L., and F. L. Bunnell. 1999. Edge effects: Theory, evidence and implications to management of western North American for- 
ests. Pages 117-153 in Forest Fragmentation: Wildlife and Management Implications (J. A. Rochelle, L. A. Lehmann, and J. Wisniewski, Eds.). Brill Academic Publishers, Boston, Massachusetts.

Ministère des Ressources Naturelles du Québec. 1996. Règlement sur les normes d'intervention dans les forêts du domaine public. Gazette Officielle du Québec 128: 2750-2786.

Møller, A. P. 1989. Nest site selection across fieldwoodland ecotones: The effect of nest predation. Oikos 56:240-246.

Nour, N., E. Matthysen, And A. Dhondt. 1993. Artificial nest predation and habitat fragmentation: Different trends in bird and mammal predators. Ecography 16:111-116.

Ouellet, H. 1970. Further observations on food and predatory habits of the Gray Jay. Canadian Journal of Zoology 48:327-330.

Otis, D. L., And G. C. White. 1999. Autocorrelation of location estimates and the analysis of radiotracking data. Journal of Wildlife Management 63:1039-1044.

PArent, B. 1999. Ressource et industrie forestière: Portrait statistique. Gouvernement du Québec, Ministère des Ressources naturelles, Charlesbourg, Québec.

Rail, J.-F., M. Darveau, A. Desrochers, AND J. Нuот. 1997. Territorial responses of boreal forest birds to habitat gaps. Condor 99:976-980.

Redpath, S. M. 1995. Habitat fragmentation and the individual: Tawny Owls Strix aluco in woodland patches. Journal of Animal Ecology 64:652-661.

Ricklefs, R. E. 1969. An analysis of nesting mortality in birds. Smithsonian Contributions to Zoology, no. 9.
Sieving, K. E., And M. F. Willson. 1998. Nest predation and avian species diversity in northwestern forest understory. Ecology 79: 2391-2402.

Sisk, T. D., AND C. R. MARgules. 1993. Habitat edges and restoration: Methods for quantifying edge effects and predicting the results of restoration efforts. Pages 57-69 in Nature Conservation 3: Reconstruction of Fragmented Ecosystems (D. Saunders, R. J. Hobbs, and P. R. Ehrlich, Eds.). Surrey Beatty and Sons, Sydney, Australia.

Sklepкоvych, B. 1997. Kinship and conflict: Resource competition in a proto-cooperative species, the Siberian Jay. Ph.D. dissertation, University of Stockholm, Sweden.

Strickland, D., and H. Ouellet. 1993. Gray Jay (Perisoreus canadensis). In The Birds of North America, no. 40 (A. Poole, P. Stettenheim, and F. Gill, Eds.). Academy of Natural Sciences, Philadelphia, and American Ornithologists' Union, Washington, D.C.

Tewksbury, J. J., S. J. Hejl, and T. E. Martin. 1998. Breeding productivity does not decline with increasing fragmentation in a western landscape. Ecology 79:2890-2903.

Vickery, P. D., M. L. Hunter, Jr., And J. V. Wells. 1992. Is density an indicator of breeding success? Auk 109:706-710.

White, G. C., And R. A. Garrot. 1990. Analysis of Wildlife Radio-Tracking Data. Academic Press, San Diego, California.

Yahner, R. H., And N. H. Piergallini. 1998. Effects of microsite selection on predation of artificial ground nests. Wilson Bulletin 110:439-442.

Associate Editor: M. Brittingham 